\title{
A szelénellátás hatása a kukorica és napraforgó növényekre
}

\author{
${ }^{1}$ NAGY KINGA-2 LÉVAI LÁSZLÓ- ${ }^{1}$ KOVÁCS BÉLA \\ Debreceni Egyetem, Agrár- és Múszaki Tudományok Centruma \\ ${ }^{1}$ Élelmiszertudományi, Minôségbiztosítási és Mikrobiológiai Intézet \\ ${ }^{2}$ Növénytudományi Intézet, Mezőgazdasági Növénytani és \\ Növényélettani Tanszékcsoport
}

\begin{abstract}
Összefoglalás
A növények szeléntartalmát leginkább a talaj felvehetô szeléntartalma befolyásolja. Számos európai országban, így Magyarországon is, a talajok szelénben meglehetôsen szegények.

Kísérleteinkben, talajon (rizoboxos kísérlet) és tápoldaton, kontrollált körülmények között végzett szelénellátás hatását vizsgáltuk, egy egyszikú (kukorica), illetve egy kétszikú (napraforgó) növénynél. A rizoboxos és a tápoldatos kísérleteinkben a szelént szelenit $(1,10,100 \mathrm{mg} / \mathrm{kg})$, illetve szelenát $(0,1,1,10 \mathrm{mg} / \mathrm{kg})$ formában adagoltuk, a kontroll $(\varnothing)$ növények nem kaptak szelén kezelést.

A Se-kezelések hatására a növények Se-tartalma jelentősen megemelkedett. Ez a növekedés a szelenát kezelés hatására intenzivebb volt, mint a szelenit kezelésnél, ugyanakkora koncentrációjú kezelések esetében. A kísérleti növények hajtásának és gyökerének külön történô vizsgálata alapján megállapítottuk, hogy a kukoricánál, és a napraforgónál a Se-koncentrációk nagyobbak voltak a gyökérben, mint a hajtásban. Ez arra utal, hogy a szelén akkumulációja intenzívebb volt a gyökerekben, miközben a hajtásba történô transzlokációja akadályázott.

A tápoldatban és rizoboxban (talajban), a szelenit és szelenát kezelés hatására a hajtásban a következô szeléntartalom növekedéseket tapasztaltunk:
\end{abstract}


1. Tápoldatban

\begin{tabular}{l|c|c} 
& egyszikú (kukorica) & kétszikú (napraforgó) \\
\hline szelenit kezelés hatására: & $1176 \times$ & $104 \times$ \\
& $(0,461$ és $542 \mathrm{mg} / \mathrm{kg} \mathrm{Se})$ & $(1,38$ és $143 \mathrm{mg} / \mathrm{kg} \mathrm{Se})$ \\
szelenát kezelés hatására: & $736 \times$ & $221 \times$ \\
& $(0,654$ és $482 \mathrm{mg} / \mathrm{kg} \mathrm{Se})$ & $(2,97$ és $656 \mathrm{mg} / \mathrm{kg} \mathrm{Se})$ \\
\hline
\end{tabular}

A zárójelben a legkisebb, azaz kontroll (Ø) és a legnagyobb, azaz szelenit esetén 100 $\mathrm{mg} / \mathrm{kg}$, míg szelenát esetén $10 \mathrm{mg} / \mathrm{kg}$ kezelést kapott növények hajtásának szelén tartalma található.

2. Rizoboxban

\begin{tabular}{l|c|c} 
& egyszikú (kukorica) & kétszikú (napraforgó) \\
\hline szelenit kezelés hatására: & $45 \times$ & $41 \times$ \\
& $(0,736$ és $32,8 \mathrm{mg} / \mathrm{kg} \mathrm{Se})$ & $(0,249$ és $10,3 \mathrm{mg} / \mathrm{kg} \mathrm{Se})$ \\
szelenát kezelés hatására: & $775 \times$ & $859 \times$ \\
& $(0,736$ és $570 \mathrm{mg} / \mathrm{kg} \mathrm{Se})$ & $(0,249$ és $214 \mathrm{mg} / \mathrm{kg} \mathrm{Se})$ \\
\hline
\end{tabular}

A zárójelben a legkisebb, azaz kontroll (Ø) és a legnagyobb, azaz szelenit esetén 100 $\mathrm{mg} / \mathrm{kg}$, míg szelenát esetén $10 \mathrm{mg} / \mathrm{kg}$ kezelést kapott növények hajtásának szelén tartalma található.

Kulcsszavak: szelén, kukorica, napraforgó, rizobox, tápoldat

\title{
The effect of selenium supply on maize and sunflower
}

\author{
${ }^{1}$ K. NAGY-2L. LÉVAI- ${ }^{1}$ B. KOVÁCS \\ University of Debrecen, Centre of Agricultural Sciences and Engineering \\ ${ }^{1}$ Institute of Food Sciences, Quality Assurance and Microbiology \\ ${ }^{2}$ Institute of Crop Sciences, Faculty Group of Agricultural Botany and \\ Plant Physiology
}




\section{Summary}

The Selenium content of crops is mainly determined by the accessible Selenium content of the soil. In Hungary - similarly to several European countries -, soils are rather Seleniumdeficient.

In our experiments in soil ('rhizobox') and in nutrient solution, we examined the effect of Selenium supply under controlled conditions, using a monocotyledonous (maize) and a dicotyledonous (sunflower) crop. In the rhizobox and nutrient solution experiments, we applied Selenium in the forms of Selenite $\left(1,10,100 \mathrm{mg} \mathrm{kg}^{-1}\right)$ and Selenate $\left(0,1,1,10 \mathrm{mg} \mathrm{kg}^{-1}\right)$ respectively, whereas there was no Selenium treatment on the control crops $(\varnothing)$.

As a result of Se treatments, the Se contents of crops significantly increased. This increase was more intensive as a result of Selenate treatment in comparison with the Selenite treatment, considering identical concentrations in both cases. Based on the separate examinations of the shoots and roots of the experimental plants, we concluded that Se concentrations were higher in the root than in the shoot concerning both maize and sunflower. This phenomenon indicates that the accumulation of Selenium was more intensive in the roots, whereas its translocation into the shoot is blocked.

As a result of the Selenite and Selenate treatments both in the nutrient solution and the rhizobox (soil), we observed the following increases in Selenium content:

1) Nutrient solution

\begin{tabular}{l|c|c} 
& $\begin{array}{c}\text { monocotyledonous } \\
\text { (maize) }\end{array}$ & $\begin{array}{c}\text { dicotyledonous } \\
\text { (sunflower) }\end{array}$ \\
\hline $\begin{array}{l}\text { as a result of selenite } \\
\text { treatment: }\end{array}$ & $\begin{array}{c}1176 \times \\
\left(0.461 \text { and } 542 \mathrm{mg} \mathrm{kg}^{-1} \mathrm{Se}\right)\end{array}$ & $\begin{array}{c}104 \times \\
\left(1.38 \text { and } 143 \mathrm{mg} \mathrm{kg}{ }^{-1} \mathrm{Se}\right)\end{array}$ \\
$\begin{array}{l}736 \times \\
\text { as a result of selenate } \\
\text { treatment: }\end{array}$ & $\begin{array}{c}221 \times \\
(0.654 \mathrm{and} 482 \mathrm{mg} \mathrm{kg} \cdot \mathrm{Se})\end{array}$ & $\left(2.97\right.$ and $\left.656 \mathrm{mg} \mathrm{kg}^{\cdot-1} \mathrm{Se}\right)$ \\
\hline
\end{tabular}

In parantheses, we indicated the Selenium contents of the shoots in the case of the lowest (control [Ø]) and the highest (100 mg kg-1 for Selenite and $10 \mathrm{mg} \mathrm{kg}^{-1}$ for Selenate) treatments. 
2) Rootbox

\begin{tabular}{l|c|c} 
& $\begin{array}{c}\text { monocotyledonous } \\
\text { (maize) }\end{array}$ & $\begin{array}{c}\text { dicotyledonous } \\
\text { (sunflower) }\end{array}$ \\
\hline $\begin{array}{l}\text { as a result of selenite } \\
\text { treatment: }\end{array}$ & $\begin{array}{c}45 \times \\
\left(0.736 \text { and } 32.8 \mathrm{mg} \mathrm{kg}^{-1} \mathrm{Se}\right)\end{array}$ & $\begin{array}{c}41 \times \\
\left(0.249 \text { and } 10.3 \mathrm{mg} \mathrm{kg}^{-1} \mathrm{Se}\right) \\
\begin{array}{l}775 \times \\
\text { as a result of selenate }\end{array}\end{array}$ \\
\begin{tabular}{l} 
treatment: \\
\hline
\end{tabular}
\end{tabular}

In parantheses, we indicated the Selenium contents of the shoots in the case of the lowest (control [Ø]) and the highest (100 $\mathrm{mg} \mathrm{kg}^{-1}$ for Selenite and $10 \mathrm{mg} \mathrm{kg}^{-1}$ for Selenate) treatments.

Key words: Selenium, maize, sunflower, rhizobox, nutrient solution

\section{Bevezetés és szakirodalmi áttekintés}

A szelén az egész Föld felszínén jelen van: majdnem minden kőzetben, talajban, vízben. Elemi formában ritkán, többnyire szelénsav, szelénoxid, szelénsó (szelenit, szelenát) formában található meg (Bankhofer 1994).

A talaj szeléntartalma Takács (2001) szerint 0,1-10 $\mu \mathrm{g} / \mathrm{g}$. A szelénhiányos területeken 0,005-2,0 $\mu \mathrm{g} / \mathrm{g}$. Egyes seleniferous talajokban viszont akár több száz $\mu \mathrm{g} / \mathrm{g}$ értéket is mértek (Kádár 1998). A termótalajok világátlaga $0,4 \mathrm{mg} / \mathrm{kg}$, hazai talajaink 0,3-0,6 mg/kg szelént tartalmaznak (Simon 1999). Számos tényezô befolyásolja a Se-tartalmat, legmeghatározóbb a talaj anyakőzete. A csapadék menynyiség is befolyásoló tényező, száraz talajokban nagyobb Se-értéket mértek (Aubert és Pinta 1977).

A Föld sok részén találhatók olyan területek, ahol a talaj szeléntartalma eredendően nagyon alacsony. Egyes területeken csak a késóbbiekben alakult ki szelénhiány a túl sok mútrágya kontroll nélküli alkalmazása, és az ammóniumszulfáttal való túltrágyázás hatására. A talaj hirtelen kémiai változását okozhatják a savas esók, amelyek nagy mennyiségben kénsavat, valamint kéntartalmú fosszilis égéstermékeket juttatnak a talajba. A szelén ennek hatására lekötôdik, és a növények számára felvehetetlen lesz (Bankhofer 1994). A talajok szeléntartalma 
mikrobiális hatásra is csökkenhet, mivel a mikroorganizmusok a szelént képesek metilálni és illékonnyá tenni. Szelén kerülhet be a termőtalajainkba foszfor mútrágyákból, nyersfoszfátokból (Simon 1999).

A talajban a szelén mobilitását számos tényezó befolyásolja: a talaj hômérséklete, víztartalma, szerves anyag tartalma, az évszaki jellemzők, illetve a talajban lejátszódó mikrobiális tevékenységek. Savas, redukáló és szerves anyagban gazdag talajban a nem mobilis és felvehetetlen szelenid és elemi szelén, míg lúgos, oxidatív, szellőzött talajban, a szelenit és a szelenát oxidációs formák dominálnak, melyek mobilisak, felvehetők és toxikusak is lehetnek. A szelenátok általában egy nagyságrenddel jobban felvehetők a növények számára, mint a szelenitek, így mérgezőbbek is (Kádár 1998). A szelenát a szelénformák közül a legmobilisabb, ami a komponens nagy oldékonyságán és a talaj szemcséin való gyenge adszorpcióján alapszik. A jobb biológiai hozzáférhetôség miatt így a vízoldékony szelén vegyületek a veszélyesebbek. Az elemi szelén sokkal kevésbé mobilis és oldékony, így az emberi szervezet számára ez a szelénforma nem jelent komolyabb mérgezési forrást (Kápolna 2006). A különböző Se-formák átalakulhatnak, egymásba átmehetnek, amennyiben a talajtulajdonságok megváltoznak, pl. elsavanyodnak (Kádár 1998).

„Szelénben szegény talajok nátrium-szelenáttal vagy szelenittel történő kezelése során igen körültekintően kell tehát eljárni, mivel a takarmánynövényekbe toxikus mennyiségú szelén kerülhet be. A szennyezôdést elkerülendô, célszerú a szelénsókat a levelekre permetezni, vagy a magvakat szeléntartalmú oldatba áztatni" (Simon 1999).

A talajszennyezés kezelésére viszont jó megoldást jelenthet a fitoremediáció. A szelént intenziven felhalmozni képes növényeket ültetnek a szennyezett területekre, és a növények eltávolításával, majd újbóli telepítésével lassan eltávolítják a szennyezést a talajból. Ez az eljárás olcsó, és az eddigi kísérletek alapján igen hatékony is (Széles 2007). A nagy szeléntartalmú növények további kezelése viszont újabb kérdéseket vethet fel.

Mivel több európai országhoz hasonlóan, Magyarországon is, a talajok szelénben meglehetôsen szegények, valamint a növény szeléntartalmát főként a talaj felvehetô szeléntartalma szabja meg, továbbá a növényi eredetú élelmiszeripari termékek fogyasztásával biztosítható szelén bevitel csak töredéke a szükségesnek, ezért elengedhetetlen, hogy megvizsgáljuk a növények szelénfelvételét, növény-tápoldat, valamint növény-talaj rendszer használatával. 
A szelénellátás kutatásának egyik szegmense a tápanyagok szeléntartalmát befolyásoló tényezôk vizsgálata. A kutatás komplex, és tudományágak együttmúködését igényli.

A növények szeléntartalmát a növény fajtája, növekedési állapota, a talaj szelénellátottsága, és a Se kémiai formája határozza meg (Lteif et al. 2005). Csak a biológiailag elérhető formákat képes a növény felvenni a környezetből (Chengyi et al. 2005). A talaj szerves anyagához kötött szelén nem mobilis és csak egyes indikátor fajok számára felvehető. Ezek a növények Se-transzformátorok, elhalásuk után kiváló Se-forrásul szolgálnak a többi faj számára (Kádár 1998). A szelén átlagos mennyiségét a növényekben 0,01-2 $\mu \mathrm{g} / \mathrm{kg}$-ra becsülik (Kovács et al. 1998b).

A magasabb rendú növények számára a Se kis koncentrációban stimulatív, kedvező hatású mikroelem, de nem esszenciális (Simon 1999). Kádár (1998) szerint az elöregedô növényekben a Se-koncentráció gyakran a tizedére csökken. Szelénfölösleg növekedésgátlást okoz, klorotikus tünetek alakulnak ki, feltételezhetôen a növények kénanyagcseréjét zavarja meg (Simon 1999).

A növények a szervetlen szeléntartalmú vegyületet szerves szeléntartalmú vegyületté alakítják át, így az emberi szervezet számára is felhasználhatóvá válik (Bankhofer 1994). A gyökérben, a fiatal hajtásban, levélben, a szárban, és a szemtermésben mért szelén csökkenő koncentrációt mutat, ami a növényben egy sajátos szúrôrendszert képez (Kádár 1995).

Bizonyos növények képesek arra, hogy szervezetükben feldúsítsák a szelént, ezeket Se-akkumulátoroknak nevezzük (Robb és Pierpoint 1983). Legtöbb növény nem Se-akkumuláló, hanem Se-érzékeny (Terry et al. 2000).

A Se-felvételben és akkumulációban a különböző növényfajok nagy változatosságot mutatnak. Az Astragalus, Xylorrhiza és Stanleya nemzetség sok faja tipikus Se-akkumulátor, és képes nagy Se-tartalmú (seleniferous) talajon megélni káros hatás nélkül, és a hajtásaik Se-tartalma elérheti a 20-30 mg/g értéket szárazanyagra számítva. Nagy különbségek vannak azonban az Astragalus nemzetségen belül az egyes fajok között is, ugyanis az akkumulátorok 100-200-szor több szelént tartalmaznak, mint a nem-akkumulátor fajok (Marschner 1995).

Schwarz és Foltz (1957) jelentette ki először, hogy a szelén „esszenciális”, azaz életfontosságú nyomelem. Az emberi szervezetnek az egészséghez nélkülözhetetlen funkciók fenntartásához meghatározott mennyiségú szelénre van szüksége. Tehát Paracelsus mondata érvényes a szelénre is: „Az adagtól függ, hogy valami méregnek, vagy gyógyszernek minösül-e...”. 
A szelén esszenciális mikroelem, fiziológiai szerepét fokozza, hogy antioxidáns szereppel bír. Védi a sejteket a szabadgyökök okozta károsító hatásokkal szemben, és hozzájárul az immunrendszer egészséges múködéséhez. Hiányát összefüggésbe hozzák az általános ellenálló képesség csökkenésével, a szív- és érrendszeri, valamint a daganatos betegségek kialakulásával. A reuma, az artritisz, a leukémia, a fiatalkori krónikus izületgyulladás, a cukorbetegség, a búskomorság, a vérszegénység, a bölcsőhalál, a terhesség alatti depresszió, az Alzheimer-kór, az asztma, a korpásodás, a fáradékonyság, a májbetegség, valamint a kis születési súly és a hasnyálmirigy-gyulladás oka részben a szelénhiány lehet. (Széles 2007).

Magyarországon a vezetô halálozási okok között dominánsak a szív, az érrendszeri, valamint a daganatos betegségek. Az orvosi diagnosztikai eljárásokban és a gyógyításban bekövetkezett fejlôdés ellenére, több mint 7 millió ember hal meg évente daganatos megbetegedésekben, a WHO felmérése alapján. A tudomány jelenlegi állása szerint a betegségek harmada megelőzhető lehetne.

Egészségi állapotunkat elsôsorban - a genetikai adottságok mellett - az életmódunk határozza meg. A betegségmegelőzésben fontos szerepet játszik a helyes étrend, a vitamin, az ásványi anyagok, valamint a megfelelô mennyiségú antioxidánsok bevitele. Az orvostudománynak, az ok-okozati összefüggésekre alapozott gyógyító munkája a prevención alapszik. A betegségek megelőzéséhez a szelénkutatás nagyban hozzájárulhat.

\section{Anyag és módszer}

Kísérleteinkben kukoricát (Zea mays L. cv Reseda), illetve napraforgót (Helianthus annuus L. cv Arena PR) használtunk. A szelént nátrium-szelenit $\left(\mathrm{Na}_{2} \mathrm{SeO}_{3} .5 \mathrm{H}_{2} \mathrm{O}\right)$ (Fluka, Buchs, Svájc) és nátrium-szelenát $\left(\mathrm{Na}_{2} \mathrm{SeO}_{4}\right)$ (SigmaAldrich, Steinheim, Németország) formájában ioncserélt vízben feloldva alkalmaztuk, amely során a szükséges koncentrációt szelénre vonatkoztatva számoltuk ki. A kísérleteinkben szelenit esetén 1, 10, $100 \mathrm{mg} / \mathrm{kg}$, szelenát esetén pedig $0,1,1,10 \mathrm{mg} / \mathrm{kg}$ szelén koncentrációt, továbbá kontroll ( $\varnothing$ ) kezelést alkalmaztunk. Minden kezelésnél három ismétlést használtunk.

A növények nevelésére a Növénytudományi Intézet, Mezőgazdasági Növénytani és Növényélettani Tanszékcsoport Klímaszobájában került sor.

A 2,5 l-es edényekben végzett, tápoldatos kísérlet során, az egyes tápoldatos edényekbe 10 db 2,5-3,0 cm koleoptillal rendelkező kukorica csíranövényt és 
$3 \mathrm{~cm}$-es hipokotilú napraforgó csíranövényt helyeztünk tápoldatra. A fenti növények magját 2009. 05. 04-én kezdtük csíráztatni $\left(22^{\circ} \mathrm{C}\right.$-on termosztátban, függólegesen állított nedves szúrôpapírok között), majd május 8-án a kukoricát, május 9-én a napraforgót raktuk a tápoldatra és az összes kísérleti növény mintavételét május 21-én végeztük el.

Az egyszikú növények nevelésére a következó összetételú tápoldatot alkalmaztuk: 2,0 mM Ca( $\left.\mathrm{NO}_{3}\right) 2 ; 0,7 \mathrm{mM} \mathrm{K}_{2} \mathrm{SO}_{4} ; 0,5 \mathrm{mM} \mathrm{MgSO}_{4} ; 0,1 \mathrm{mM} \mathrm{KH}_{2} \mathrm{PO}_{4}$; $0,1 \mathrm{mM} \mathrm{KCl} ; 0,1 \mu \mathrm{M} \mathrm{H}_{3} \mathrm{BO}_{3} ; 0,5 \mu \mathrm{MnSO}_{4} ; 0,5 \mu \mathrm{MnSO}_{4} ; 0,2 \mu \mathrm{M} \mathrm{CuSO}_{4} ; 0,01$ $\mu \mathrm{M}\left(\mathrm{NH}_{4}\right)_{6} \mathrm{Mo}_{7} \mathrm{O}_{24}$.

A kétszikú növények nevelésére pedig a következô összetételú tápoldatot alkalmaztuk: 2,0 $\mathrm{mM} \mathrm{Ca}\left(\mathrm{NO}_{3}\right)_{2} ; 0,7 \mathrm{mM} \mathrm{K}_{2} \mathrm{SO}_{4} ; 0,5 \mathrm{mM} \mathrm{MgSO}_{4} ; 0,1 \mathrm{mM}$ $\mathrm{KH}_{2} \mathrm{PO}_{4} ; 0,1 \mathrm{mM} \mathrm{KCl} ; 10 \mu \mathrm{M} \mathrm{H}_{3} \mathrm{BO}_{3} ; 0,5 \mu \mathrm{MnSO}_{4} ; 0,5 \mu \mathrm{M} \mathrm{ZnSO}_{4} ; 0,2 \mu \mathrm{M}$ $\mathrm{CuSO}_{4} ; 0,01 \mu \mathrm{M}\left(\mathrm{NH}_{4}\right)_{6} \mathrm{Mo}_{7} \mathrm{O}_{24}$.

A növények a vasat $10^{-4} \mathrm{M}$ koncentrációjú Fe-EDTA formájában kapták.

A környezeti feltételek szabályozottak voltak: a fényintenzitás $220 \mu \mathrm{Em}^{2} \mathrm{~s}^{-1}$, a hómérséklet periodicitása $25 / 20{ }^{\circ} \mathrm{C}$ (nappal/éjjel), a relatív páratartalom (RH) 65-75\%, a megvilágítás/sötét periódus 16 óra/8 óra. A tápoldatok levegôztetése folyamatos volt.

A rizoboxban végzett kísérletekhez a DE AMTC Látóképi Kísérleti Telepérôl származó mészlepedékes csernozjom talajt használtuk, mely jellemzőit az 1. táblázatban tüntettük fel.

A vizsgálatainkhoz $23,5 \mathrm{~cm} \times 10 \mathrm{~cm} \times 1 \mathrm{~cm}$ dimenziójú rizoboxokat alkalmaztunk, melybe $3 \mathrm{db} 2,5-3,0 \mathrm{~cm}$ koleoptillal rendelkezó kukorica csíranövényt és $3 \mathrm{db} 3 \mathrm{~cm}$-es hipokotilú napraforgó csíranövényt helyeztünk. A talaj elôkészítéséhez 6 mm-es lyukátmérôjú szitát használtunk. A talajt tömegállandóságig szárítottuk, majd a szántóföldi vízkapacitás 50\%-áig benedvesítettük, a kezeléseknek megfelelő Se-oldatok alkalmazásával. Mielőtt a talajt a rizoboxokba raktuk, az egyes rizoboxok aljára ioncserélt vízzel benedvesített szúrôpapírt helyeztünk. Ezáltal biztosítottuk az egyenletes vízfelvételt a növények számára. Naponta mértük az egyes rizoboxok tömegét, az egyes növények gyökereinek hosszát és a leadott vízmennyiséget szintén naponta pótoltuk. A rizoboxos kísérletben, a 2 napig csírázott növényeket, szeptember 3-án raktuk a rizoboxokba, majd szeptember 7 -én vettük az összes mintát. 
1. táblázat. A rizoboxban végzett kísérletekhez alkalmazott talaj jellemző $i$

\begin{tabular}{|c|c|}
\hline Mélység (1) & $0-0,3 \mathrm{~m}$ \\
\hline $\mathrm{pH}(\mathrm{KCl})$ & 5,71 \\
\hline $\mathrm{pH}\left(\mathrm{H}_{2} \mathrm{O}\right)$ & 6,58 \\
\hline Arany-féle kötöttség (KA) (2) & 43 \\
\hline Vízoldható összes só (3) & $0,015 \%$ \\
\hline $\mathrm{CaCO}_{3}$ & $0,202 \%$ \\
\hline Humusz (4) & $3,54 \%$ \\
\hline KCL-oldható $\mathrm{NO}_{3}-\mathrm{N}+\mathrm{NO}_{2}-\mathrm{N}$ (5) & 8,04 \\
\hline AL-oldható $\mathrm{P}_{2} \mathrm{O}_{5}(6)$ & $199 \mathrm{mg} / \mathrm{kg}$ \\
\hline AL-oldható $\mathrm{K}_{2} \mathrm{O}(7)$ & $451 \mathrm{mg} / \mathrm{kg}$ \\
\hline AL-oldható Na (8) & $332 \mathrm{mg} / \mathrm{kg}$ \\
\hline KCl-oldható Mg (9) & $176 \mathrm{mg} / \mathrm{kg}$ \\
\hline KCl-oldható $\mathrm{SO}_{i}-\mathrm{S}(10)$ & $6,04 \mathrm{mg} / \mathrm{kg}$ \\
\hline KCl-EDTA- oldható Cu (11) & $5,79 \mathrm{mg} / \mathrm{kg}$ \\
\hline KCl-EDTA oldható Zn (12) & $7,9 \mathrm{mg} / \mathrm{kg}$ \\
\hline KCl-EDTA oldható Mn (13) & $262 \mathrm{mg} / \mathrm{kg}$ \\
\hline
\end{tabular}

Table 1. Soil characteristics in the experiments carried out in rhizobox. (1) Depth, (2) Plasticity (Arany-number), (3) Total water-soluble salt content, (4) Humus, (5) KCl-soluble $\mathrm{NO}_{3}-\mathrm{N}+\mathrm{NO}_{2}-\mathrm{N}$, (6) AL-soluble $\mathrm{P}_{2} \mathrm{O}_{5}$, (7) AL-soluble $\mathrm{K}_{2} \mathrm{O}$, (8) AL-soluble Na, (9) KCl-soluble Mg, (10) $\mathrm{KCl}$-soluble $\mathrm{SO}_{4} \mathrm{~S}$, (11) KCl-EDTA-soluble $\mathrm{Cu}$, (12) KCl-EDTAsoluble Zn, (13) KCl-EDTA-soluble Mn.

A minták előkészítését és mérését a Debreceni Egyetem Agrár- és Múszaki Tudományok Centruma, Élelmiszertudományi, Minôségbiztosítási és Mikrobiológiai Intézetében végeztük el. A kukorica, illetve a napraforgó hajtás és gyökér részének szétválasztását ollóval végeztük (a gyökérnyak felett kb. egy cm-rel vágtuk el a növényt). A kísérleti növények gyökereit csapvízzel, 0,1 M-os HCl-val, majd ioncserélt vízzel mostuk le, végül szárítószekrényben $105^{\circ} \mathrm{C}$-on tömegállandóságig szárítottuk.

A növényminták vizsgálatához $\mathrm{HNO}_{3}-\mathrm{H}_{2} \mathrm{O}_{2}$ nedves roncsolásos mintaelőkészítési módszert alkalmaztunk (Kovács et al. 1996), mely során a kísérleti növényminták bemérése, a rendelkezésre álló minta mennyiségének megfelelôen, darálás nélkül, egészben történt. A megfelelően előkészített, hígított minták elemtartalmát induktív csatolású plazma optikai emissziós spektrométerrel (ICP-OES) (Kovács et al. 1998a) és induktív csatolású plazma tömeg- 
spektrométerrel (ICP-MS) határoztuk meg. A zavaró hatások kiküszöbölésére az utóbbi múszernél CCT üzemmódot alkalmaztunk.

A kezelésenként és ismétlésenként vizsgált hajtás- és gyökérminták mérési eredményeit egytényezós varianciaanalízissel értékeltük, melyet Microsoft Office Excel 2003 programmal végeztük el.

\section{Eredmények}

A növények tápanyagellátását illetôen a szakirodalom és a saját kutatási eredmények alapján is alapvetô különbséget kell tennünk a talajban, vagy más tápközegben végzett kísérletek között. Ha a tápoldatban a mikroelemek szintje az $1 \mathrm{mg} / \mathrm{kg}$ határ közelében van, vagy azt meghaladja, számos elem esetén, már fitotoxikus tünetekkel kell számolnunk.

\section{Tápoldatban végzett kísérlet}

A kukorica és napraforgó növekedése a nagy koncentrációjú kezelések hatására mérséklődött, ami a szárazanyag produkcióban is megmutatkozik (1. ábra).

1. ábra. Tápoldaton nevelt kukorica és napraforgó száraz tömege

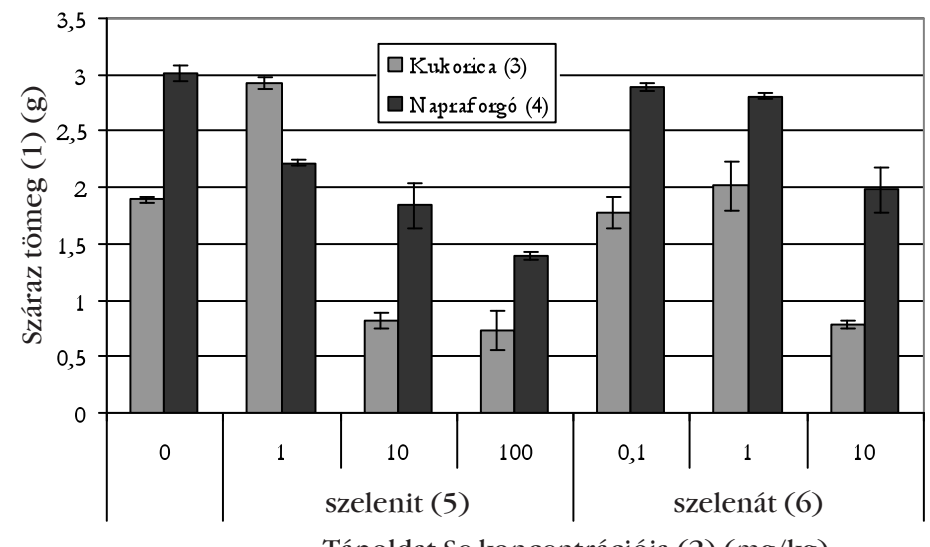

Tápoldat Se-koncentrációja (2) (mg/kg)

Figure 1. Dry mass of maize and sunflower in nutrient solution. (1) Dry mass (g), (2) Se concentration of the nutrient solution ( $\mathrm{mg} \mathrm{kg}^{-1}$ ), (3) Maize, (4) Sunflower, (5) Selenite, (6) Selenate. 
A kukorica hajtásnövekedése az $1 \mathrm{mg} / \mathrm{kg}$-os szelenit kezelés hatására fokozódott (1. kép), a további kezeléseknél viszont mérséklődött, a koncentráció függvényében. A $100 \mathrm{mg} / \mathrm{kg}$ szelenit kezelés azonban már toxikus hatású volt (2. kép).

1. kép: $1 \mathrm{mg} / \mathrm{kg}$ szelenit kezelés hatása kukoricára

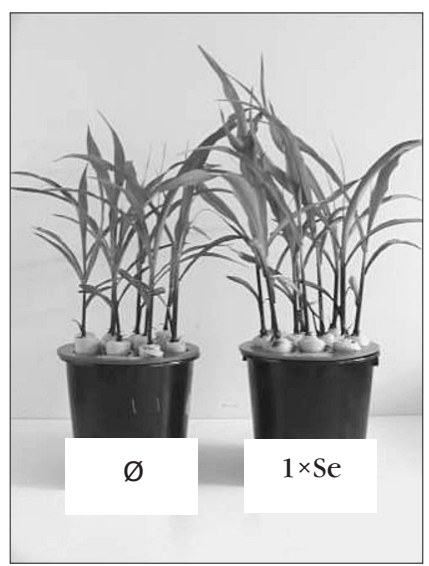

Fotók: Nagy Kinga

Picture 1: The effect of $1 \mathrm{mg} \mathrm{kg-1}^{-1}$ Selenite treatment on maize
2. kép: $100 \mathrm{mg} / \mathrm{kg}$ szelenit kezelés hatása kukoricára

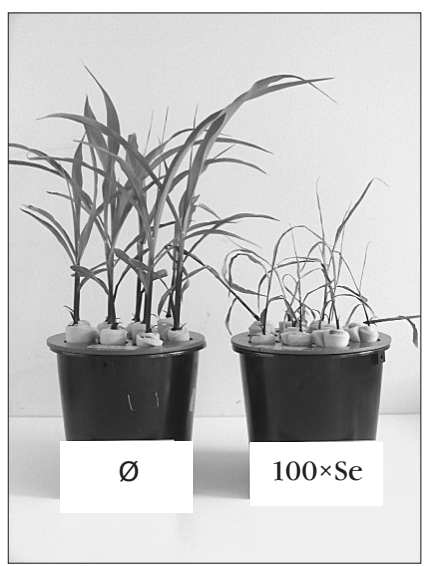

Picture 2: The effect of $100 \mathrm{mg}^{\mathrm{kg}^{-1}}$ Selenite treatment on maize

Photos: Kinga Nagy

Az egy- és a kétszikú növények tápanyagfelvételében jelentôs különbségek vannak. A kétszikúek a kationok egy részét (ilyen a vas és a cink) egy többlépcsős mechanizmuson keresztül veszik fel, melynek során proton és elektron kiválasztás történik a rizoszférába. Ez két lényeges dolgot jelent. Egyrészt a proton és elektron kiválasztás energiaigényes, azaz a már megtermelt szerves anyagok mennyiségének rovására történik, valamint kapcsolt a gyökérlégzéshez, másrészt a kiválasztás a rizoszféra elsavanyítását eredményezi, így számos tápanyag oldékonysága, ezzel együtt a felvehetôsége nó.

Az egyszikúek viszont olyan kelátképző szerves vegyületeket választanak ki, mint amilyenek a fitoszideroforok és a tápanyagokat ezekhez a kelátképzőkhöz kötötten veszik fel. Az egyszikűek tápanyagfelvétele ezért kevésbé függ a rizoszféra pH-jától. 
A két növénytípus eltérô tápanyagfelvételi mechanizmusa vezetett bennünket oda, hogy a fentebb leírt kísérletünket egy kétszikú növénnyel, a napraforgóval is elvégezzük.

A napraforgó hajtás- és gyökérnövekedése a szelenit és szelenát kezelés hatására is fokozatosan csökkent a koncentráció függvényében.

Az egyes növények relatív klorofill tartalmát mérve megállapítottuk, hogy mindkét növény esetében az idő elôrehaladtával is, de leginkább az emelkedő Se-koncentráció hatására, csökkent a relatív klorofill tartalom. Ennek okát abban látjuk, hogy a szelén gátolja a cink és a vas felvételét is. A vas különösen fontos szerepet játszik a klorofill szintézisében, ezért nem meglepô, ha a mérsékeltebb vas felvétel eredményeként csökken a klorofill mennyisége is.

A szelén nélküli tápoldaton ( $\varnothing$ ) nevelt növények szeléntartalma viszonylag alacsony volt, a növény eredetileg is meglévő szelén készletét mutatva. A szelenit kezelések hatására monoton növekedett a kukorica és a napraforgó hajtásainak is a Se-tartalma (2. táblázat).

2. táblázat. Tápoldaton nevelt kukorica és napraforgó Se-koncentrációja ( $\mathrm{mg} / \mathrm{kg}$ ) szelenit kezelések hatására

Se-koncentráció

(1)

\begin{tabular}{|c|c|c|c|c|}
\hline \multirow{2}{*}{$\begin{array}{l}\text { Szelenit- } \\
\text { kezelések } \\
\text { (2) }\end{array}$} & \multicolumn{2}{|c|}{$\begin{array}{c}\text { Kukorica } \\
\text { (3) }\end{array}$} & \multicolumn{2}{|c|}{$\begin{array}{c}\text { Napraforgó } \\
\text { (4) }\end{array}$} \\
\hline & $\begin{array}{l}\text { Hajtás } \\
(5)\left(^{*}\right)\end{array}$ & $\begin{array}{l}\text { Gyökér } \\
\text { (6) }(* *)\end{array}$ & $\begin{array}{l}\text { Hajtás } \\
(5)(* * *)\end{array}$ & $\begin{array}{l}\text { Gyökér } \\
\text { (6) }(* *)\end{array}$ \\
\hline$\varnothing \mathrm{Se}$ & $0,461 \pm 0,0395$ & $2,05 \pm 2,02$ & $1,38 \pm 0,470$ & $2,42 \pm 1,40$ \\
\hline $1 \times \mathrm{Se}$ & $25,8 \pm 0,975$ & $485 \pm 26,7$ & $27,4 \pm 0,692$ & $297 \pm 49,4$ \\
\hline $10 \times \mathrm{Se}$ & $71,6 \pm 3,25$ & $9926 \pm 985$ & $31,1 \pm 2,39$ & $457 \pm 37,3$ \\
\hline $100 \times \mathrm{Se}$ & $542 \pm 272$ & $22207 \pm 5354$ & $143 \pm 3,04$ & $696 \pm 8,13$ \\
\hline
\end{tabular}

*: szignifikancia szint $5 \%,{ }^{* *}$ : szignifikancia szint $1 \%,{ }^{* * *}$ : szignifikancia szint $0,1 \%$

Table 2. Se concentrations ( $\mathrm{mg} \mathrm{kg}^{-1}$ ) of maize and sunflower in nutrient solution as a result of Selenite treatments. (1) Se concentration, (2) Selenite treatments, (3) Maize, (4) Sunflower, (5) Shoot, (6) Root. *:5\% level of significance, $* *: 1 \%$ level of significance, ${ }^{* * *}: 0.1 \%$ level of significance. 
Szelenát kezelés hatására a kukorica és napraforgó hajtások Se-tartalma szintén emelkedett a koncentráció függvényében (3. táblázat).

3. táblázat. Tápoldaton nevelt kukorica és napraforgó Se-koncentrációja ( $\mathrm{mg} / \mathrm{kg}$ ) szelenát kezelések hatására

\begin{tabular}{|c|c|c|c|c|}
\hline \multirow{3}{*}{$\begin{array}{l}\text { Szelenát- } \\
\text { kezelések } \\
\text { (2) }\end{array}$} & \multicolumn{4}{|c|}{$\begin{array}{l}\text { Se-koncentráció } \\
\text { (1) }\end{array}$} \\
\hline & \multicolumn{2}{|c|}{$\begin{array}{l}\text { Kukorica } \\
\text { (3) }\end{array}$} & \multicolumn{2}{|c|}{$\begin{array}{c}\text { Napraforgó } \\
(4)\end{array}$} \\
\hline & $\begin{array}{l}\text { hajtás } \\
(5)(* * *)\end{array}$ & $\begin{array}{l}\text { gyökér } \\
(6)(* * *)\end{array}$ & $\begin{array}{l}\text { hajtás } \\
(5)(* * *)\end{array}$ & $\begin{array}{l}\text { gyökér } \\
(6)(*)\end{array}$ \\
\hline$\varnothing \mathrm{Se}$ & $0,461 \pm 0,0395$ & $2,05 \pm 2,02$ & $1,38 \pm 0,470$ & $2,42 \pm 1,40$ \\
\hline $0,1 \times \mathrm{Se}$ & $2,91 \pm 0,748$ & $39,7 \pm 39,6$ & $10,5 \pm 1,07$ & $21,7 \pm 9,75$ \\
\hline $1 \times \mathrm{Se}$ & $62,7 \pm 13,1$ & $86,6 \pm 9,41$ & $479 \pm 23,1$ & $132 \pm 77,7$ \\
\hline $10 \times \mathrm{Se}$ & $482 \pm 54,3$ & $580 \pm 18,0$ & $2132 \pm 12,0$ & $260 \pm 5,79$ \\
\hline \multicolumn{5}{|c|}{$\begin{array}{l}* \text { szignifikancia szint } 5 \%, * * \text { : szignifikancia szint } 1 \%, * * * \text { szignifikanci } \\
\text { szint } 0,1 \%\end{array}$} \\
\hline \multicolumn{5}{|c|}{$\begin{array}{l}\left.\text { Table 3. Se concentrations ( } \mathrm{mg} \mathrm{kg}^{-1}\right) \text { of maize and sunflower in nutrient } \\
\text { solution as a result of Selenate treatments. (1) Se concentration, (2) } \\
\text { Selenate treatments, (3) Maize, (4) Sunflower, (5) Shoot, (6) Root. *: }{ }^{*} \% \\
\text { level of significance, }{ }^{* *}: 1 \% \text { level of significance, }{ }^{* * * *}: 0.1 \% \text { level of significance. }\end{array}$} \\
\hline
\end{tabular}

A kukorica és napraforgó gyökerei szelenit kezelés hatására lényegesen több szelént tartalmaznak, mint a hajtásaik. Az ugyanolyan koncentrációjú szelenit, illetve szelenát kezelések hatására a szelenáttal kezelt növények jóval több szelént tartalmaztak. Ebből azt a következtetést vontuk le, hogy a szelenát nagyobb mértékben vehető fel a növények számára.

Méréseink arra utalnak, hogy a szelén felvétele sokkal bonyolultabb folyamat, mint feltételeztük.

A hajtások és gyökerek szeléntartalmát összeadva ábrázoltuk az egységnyi tömegú száraz növény szelén koncentrációját a szelenát kezelés hatására (2. ábra). Megállapíthatjuk, hogy ugyanolyan tömegú napraforgó több szelént vett fel, mint a kukorica.

Ezek alapján a szelenát-kezelés ismeretében kiszámítható a teljes kukorica által felvett összes szelén mennyisége.

A tápoldatos kísérletek elônye, hogy leszúkíthetô a befolyásoló tényezôk köre. Lehetőség nyílik egy adott tápelem hatásainak a vizsgálatára, a hatás részletes körülírására. Termesztési körülmények között azonban más a helyzet. A 
talaj komplexitása jelentôsen módosíthatja a tápoldaton mért értékeket és a tapasztalatokat is.

2. ábra. Tápoldaton nevelt kukorica és napraforgó Se-koncentrációja szelenát kezelés hatására

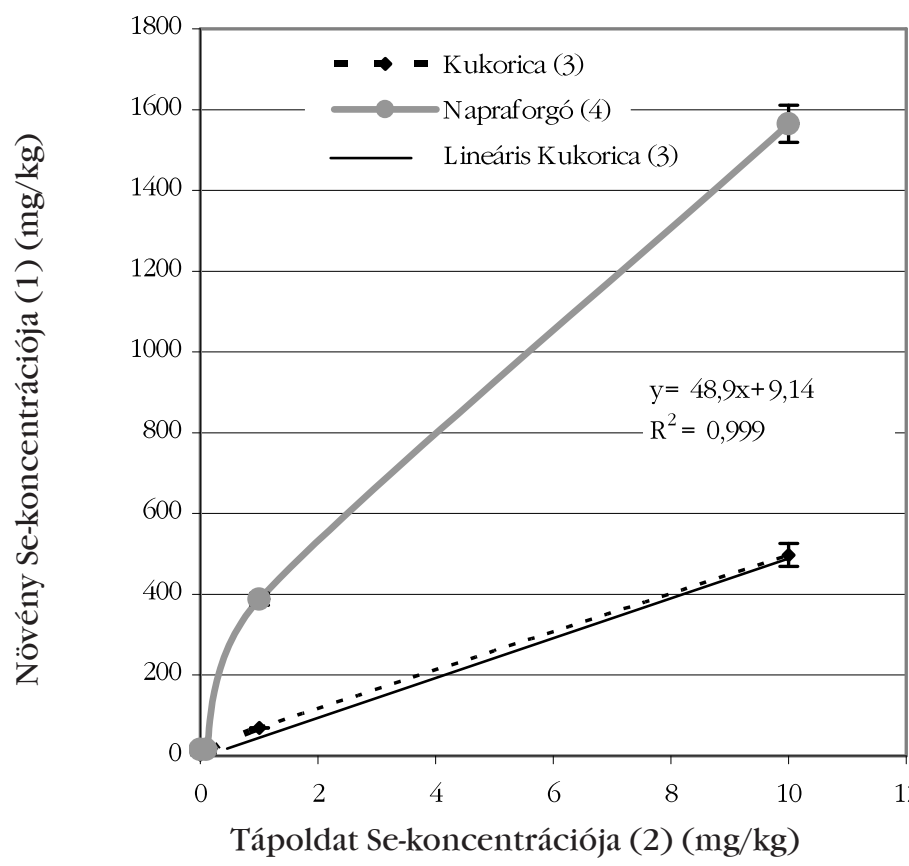

Figure 2. Se concentrations of maize and sunflower in nutrient solution as a result of Selenate treatments. (1) Se concentration of the plant $\left(\mathrm{mg} \mathrm{kg}^{-1}\right)$, (2) Se concentration of the nutrient solution $\left(\mathrm{mg} \mathrm{kg}^{-1}\right)$, (3) Maize, (4) Sunflower.

A talaj tartalmazza a tápanyagok mindegyikét, igaz eltérô koncentrációkban, ami miatt nem lehet pl. szelén nélküli körülményeket biztosítani. Jelentôs szereppel bírnak a talajlakó, kedvezó hatású mikroszervezetek is, ugyanis hozzájárulnak a legtöbb tápelem felvételéhez. Ugyanakkor a tápoldatos kísérletek útmutatásként is szolgálnak a növények fiziológiai igényét illetôen. Amennyiben a talajunk az optimálisnál kevesebb szelént tartalmaz, szükségessé válhat a szelén pótlása. A hatás nem csupán a nagyobb termésben mutatkozik meg, hanem az egészségünket szolgáló funkcionális élelmiszer 
alapanyagok, vagy élelmiszerek előállításában is. A fentiek miatt fontosnak tartottuk, hogy kísérleteinket talaj-növény rendszerben is megismételjük.

A 4. táblázatban mutatjuk be a tápoldatos vizsgálataink során statisztikai módszerekkel kimutatott szignifikáns hatásokat, miszerint a tápoldatos kísérletben a szelenit kezelések különböző dózisai, a vizsgált növényfajok (kukorica, illetve napraforgó) és a két forrás kölcsönhatása, továbbá a növényi rész (hajtás és gyökér), valamint a növényfaj és a növényi rész, illetve a dózis és növényi rész együttes hatása mutatott különböző szinten szignifikáns hatást, a vizsgált növényi részek Se-koncentrációjára. Ugyanezen kísérlet szelenát kezelésénél, a dózis, a növényfaj és ezek kölcsönhatásánál, valamint a növényfaj és a növényi rész együttes hatásánál tapasztaltunk szignifikáns különbséget.

\section{Rizoboxban végzett kisérlet}

A rizoboxban nevelt kukorica és napraforgó hajtások illetve gyökerek szelénkoncentrációját szelenit kezelés hatására az 5. táblázat, szelenát hatására a 6. táblázat tartalmazza. A talajon (rizoboxban) nevelt növények gyökerének hosszanti növekedése gátolt és az oldalgyökerek differenciálódása is visszafogott volt.

A tápoldatos kísérlethez hasonlóan a nagyobb szelén koncentrációk hatása volt kifejezettebb. Az ugyanolyan koncentrációjú szelenáttal kezelt növények több szelént tartalmaztak, mint a szelenittel kezeltek.

A kontroll talajból a kukorica és a napraforgó növény is viszonylag csekély mennyiségú szelént vett fel, a további kezeléseknél már nagyobb szelén tartalmat mértünk.

Megállapíthatjuk, hogy a kukorica és a napraforgó növények gyökerei a felvett szelént nagyobb, kb. kétszer akkora koncentrációban tartalmazták, mint a hajtások. Ez arra utal, hogy a felvett szelén hajtásba irányuló transzportja akadályozott.

Szelénnel szennyezett talaj fitoremediációval történô kezelése esetén fontos tudnunk, hogy a növények mennyi szelént tudnak felvenni a talajból, így mennyi idô alatt távolítható el a szennyezés. 


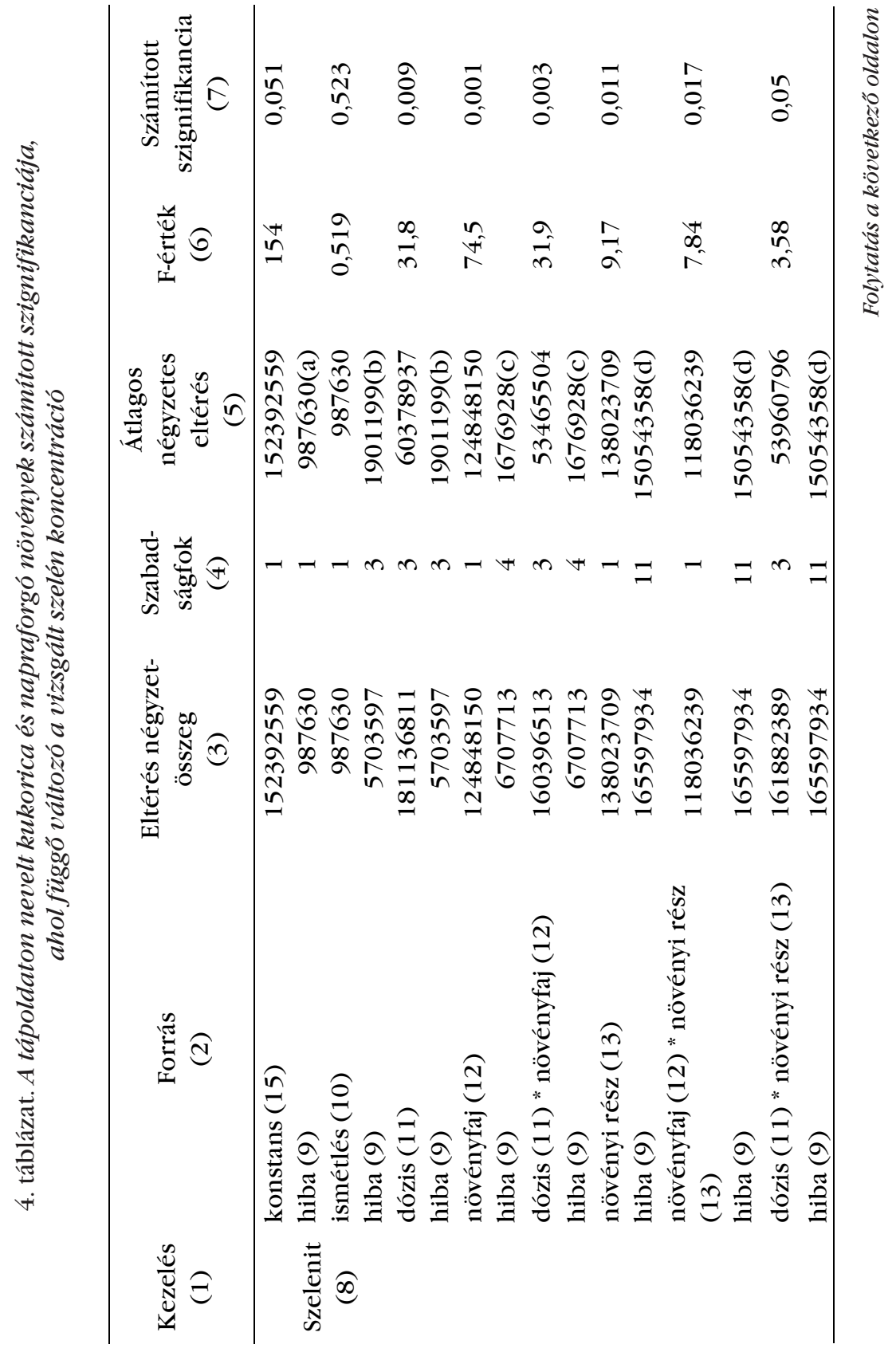




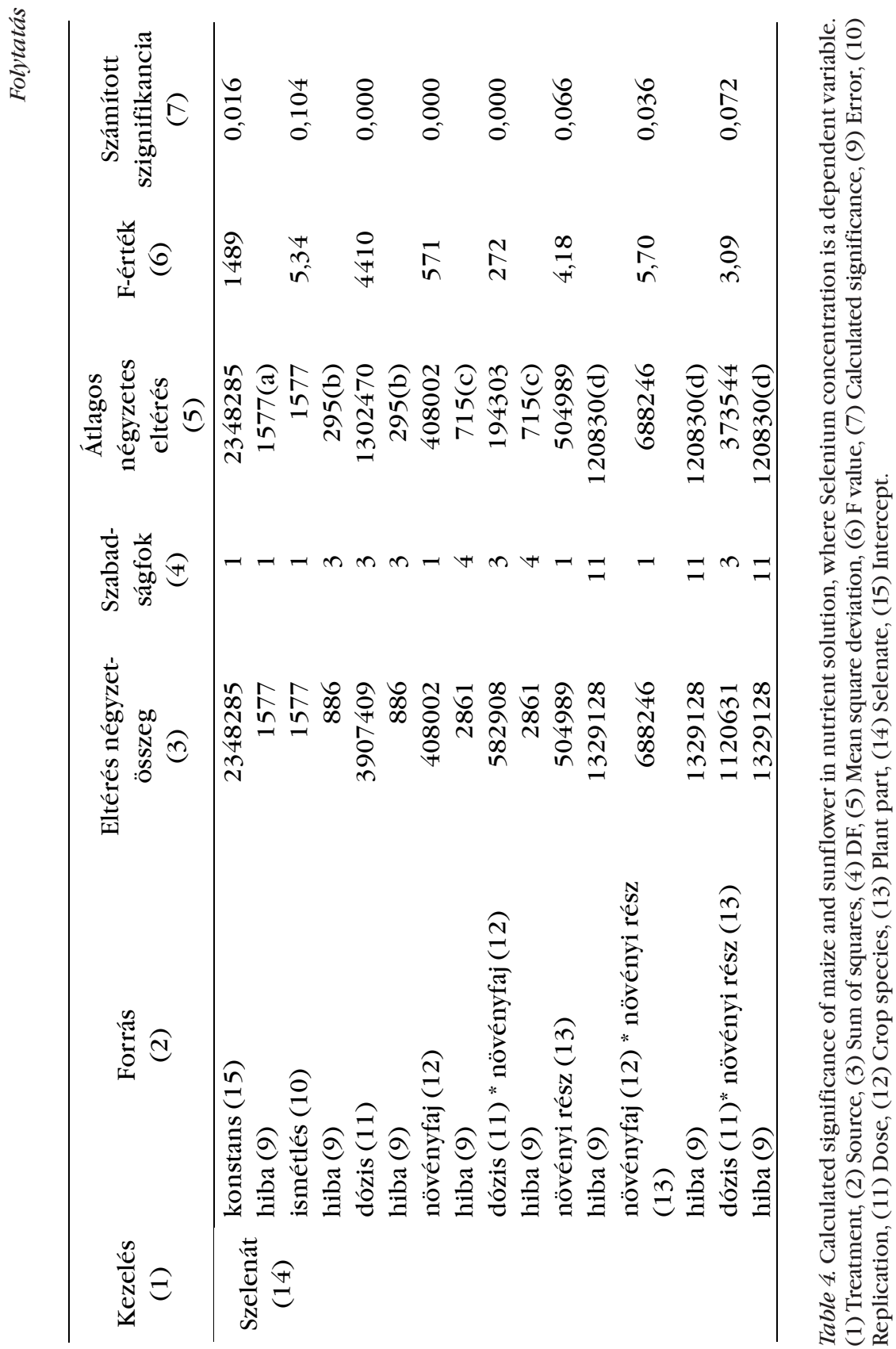


5. táblázat. Rizoboxban nevelt kukorica és napraforgó Se-koncentrációja ( $\mathrm{mg} / \mathrm{kg}$ ) szelenit kezelés hatására

Se-koncentráció

(1)

\begin{tabular}{lcccc} 
Szelenit- & \multicolumn{2}{c}{ Kukorica $(3)$} & \multicolumn{2}{c}{ Napraforgó (4) } \\
\cline { 2 - 5 } \multicolumn{1}{c}{$(2)$} & Hajtás & Gyökér & Hajtás & Gyökér \\
& $(5)(* * *)$ & $(6)(* * *)$ & $(5)(* * *)$ & $(6)(* * *)$ \\
\hline$\varnothing \mathrm{Se}$ & $0,736 \pm 0,248$ & $0,339 \pm 0,04$ & $0,282 \pm 0,163$ & $0,12 \pm 0,0346$ \\
$1 \times$ Se & $4,54 \pm 0,192$ & $3,10 \pm 1,4$ & $3,81 \pm 1,64$ & $7,11 \pm 0,607$ \\
$10 \times$ Se & $5,85 \pm 0,146$ & $11,6 \pm 1,05$ & $1,93 \pm 0,937$ & $13,8 \pm 2,71$ \\
$100 \times$ Se & $32,8 \pm 4,65$ & $162 \pm 14,5$ & $10,3 \pm 0,921$ & $341 \pm 21,2$ \\
\hline
\end{tabular}

*: szignifikancia szint $5 \%, * *$ : szignifikancia szint $1 \%,{ }^{* * *}$ : szignifikancia szint $0,1 \%$

Table 5. Se concentration ( $\left.\mathrm{mg} \mathrm{kg}^{-1}\right)$ of maize and sunflower in rhizobox as a result of Selenite treatment. (1) Se concentration, (2) Selenite treatments, (3) Maize, (4) Sunflower, (5) Shoot, (6) Root. $*: 5 \%$ level of significance, ${ }^{* *}: 1 \%$ level of significance, ${ }^{* * *}: 0.1 \%$ level of significance.

6. táblázat. Rizoboxban nevelt kukorica és napraforgó Se-koncentrációja ( $\mathrm{mg} / \mathrm{kg}$ ) szelenát kezelés hatására

\begin{tabular}{|c|c|c|c|c|}
\hline \multirow{4}{*}{$\begin{array}{l}\text { Szelenát- } \\
\text { kezelések } \\
\text { (2) }\end{array}$} & \multicolumn{4}{|c|}{$\begin{array}{c}\text { Se-koncentráció } \\
\text { (1) }\end{array}$} \\
\hline & \multicolumn{2}{|c|}{ Kukorica (3) } & \multicolumn{2}{|c|}{ Napraforgó (4) } \\
\hline & Hajtás & Gyökér & Hajtás & Gyökér \\
\hline & $(5)(* * *)$ & $(6)(* * *)$ & $(5)(* * *)$ & $(6)(* * *)$ \\
\hline$\varnothing \mathrm{Se}$ & $0,736 \pm 0,249$ & $0,339 \pm 0,04$ & $0,282 \pm 0,163$ & $0,12 \pm 0,0346$ \\
\hline $0,1 \times \mathrm{Se}$ & $13,1 \pm 1,55$ & $3,9 \pm 0,135$ & $13,9 \pm 2,00$ & $8,47 \pm 0,372$ \\
\hline $1 \times \mathrm{Se}$ & $213 \pm 42,8$ & $42,7 \pm 5,66$ & $209 \pm 39,5$ & $33,6 \pm 3,01$ \\
\hline $10 \times \mathrm{Se}$ & $570 \pm 50,4$ & $837 \pm 163$ & $213 \pm 45,6$ & $258 \pm 61,6$ \\
\hline \multicolumn{5}{|c|}{${ }^{*}:$ szignifikancia szint $5 \%,{ }^{* *}$ : szignifikancia szint $1 \%,{ }^{* * *}$ : szignifikancia szint $0,1 \%$} \\
\hline \multicolumn{5}{|c|}{$\begin{array}{l}\left.\text { Table 6. Se concentration ( } \mathrm{mg} \mathrm{kg}^{-1}\right) \text { of maize and sunflower in rhizobox as a resul } \\
\text { of Selenate treatment. (1) Se concentration, (2) Selenate treatments, (3) Maize, ( } 4 \\
\text { Sunflower, (5) Shoot, (6) Root. *: } 5 \% \text { level of significance, }{ }^{* *}: 1 \% \text { level of significance, }{ }^{* *} \\
0.1 \% \text { level of significance. }\end{array}$} \\
\hline
\end{tabular}


A 7. táblázatban találhatók a rizoboxos vizsgálataink során, a statisztikai módszerekkel kimutatott szignifikáns hatások. A rizoboxban végzett kísérlet szelenit és szelenát kezelésénél, a dózisnál, a növényfajnál, és ezek kölcsönhatásánál, továbbá a szelenitnél a különbözô növényi részeknél és a növényfajnövényi rész kölcsönhatásánál is szignifikáns különbséget tapasztaltunk. A dózis-növényi rész a rizoboxban végzett kísérlet szelenit és szelenát kezelésénél is $0,1 \%$-os szinten szignifikánsan befolyásolta a növények Se-koncentrációját.

Mindkét kísérlet az ismétlések között, valamint a szelenát kezelésénél a növényi részek között, nem volt kimutatható szignifikáns különbség.

\section{Következtetések és javaslatok}

A szelén esszenciális mikroelem, főként az állati és emberi szervezetben. Hiányában különféle betegségek fordulhatnak elő, az általános levertségtől kezdve a komolyabb szervi problémákig, hiszen a szervezet antioxidáns rendszerének nélkülözhetetlen alkotója.

A természetes szelénforrások fogyasztásával, mint például a teljes kiôrlésú gabonafélék, búzacsíra, barnarizs, diófélék, szezámmag, szója, vagy a fokhagyma, nem minden esetben biztosítható az ember számára a szükséges Se-bevitel, különösen, ha a talajok is szegények szelénben. Számos európai országban, így Magyarországon is, a talajok meglehetősen kevés szelént tartalmaznak. Ezért a szelén pótlása szükségessé válik ezeken a területeken, illetve ahol az emberek nagy része is bizonyítottan szelénhiányban szenved. Napjainkban a szelénhiányos táplálkozásból adódó betegek száma nő, így a szelénpótlás táplálkozásunkban szükségszerúnek látszik. A szelén pótlásának egyik módja lehet, hogy egy szelén só (szelenit vagy szelenát) adagolásával a talajba plusz szelént juttatunk a termesztett gazdasági növények számára. A megfelelő szelén ellátás egyik problémája, hogy a növények az esetek többségében nem mutatnak jól definiálható hiánytüneteket szelén hiányos termesztési körülmények között.

Az egészséges táplálék előállítása érdekében ezért indokolt lehet a talajok és az azon termesztett növények szelén tartalmának folyamatos monitorozása. 


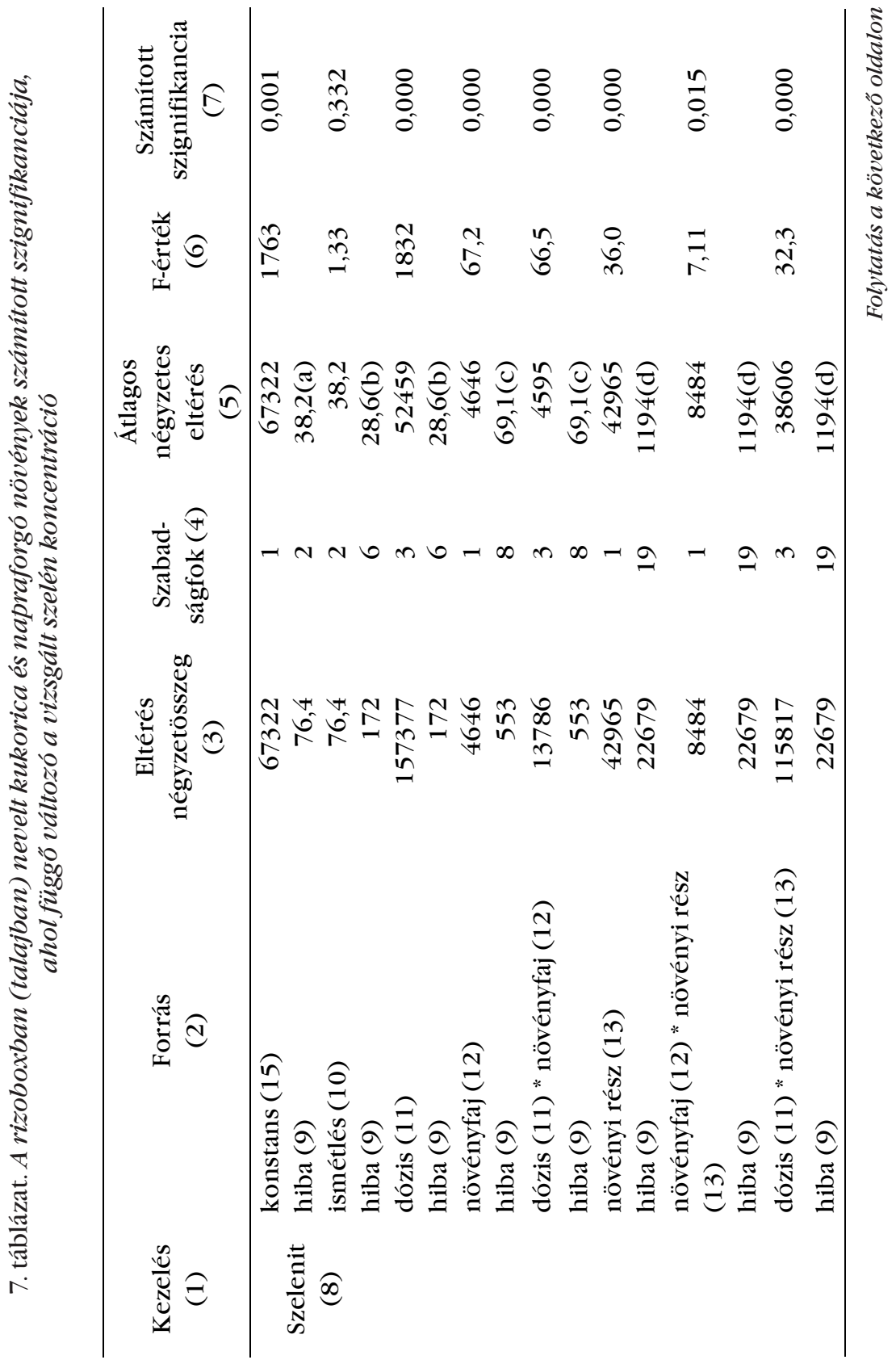




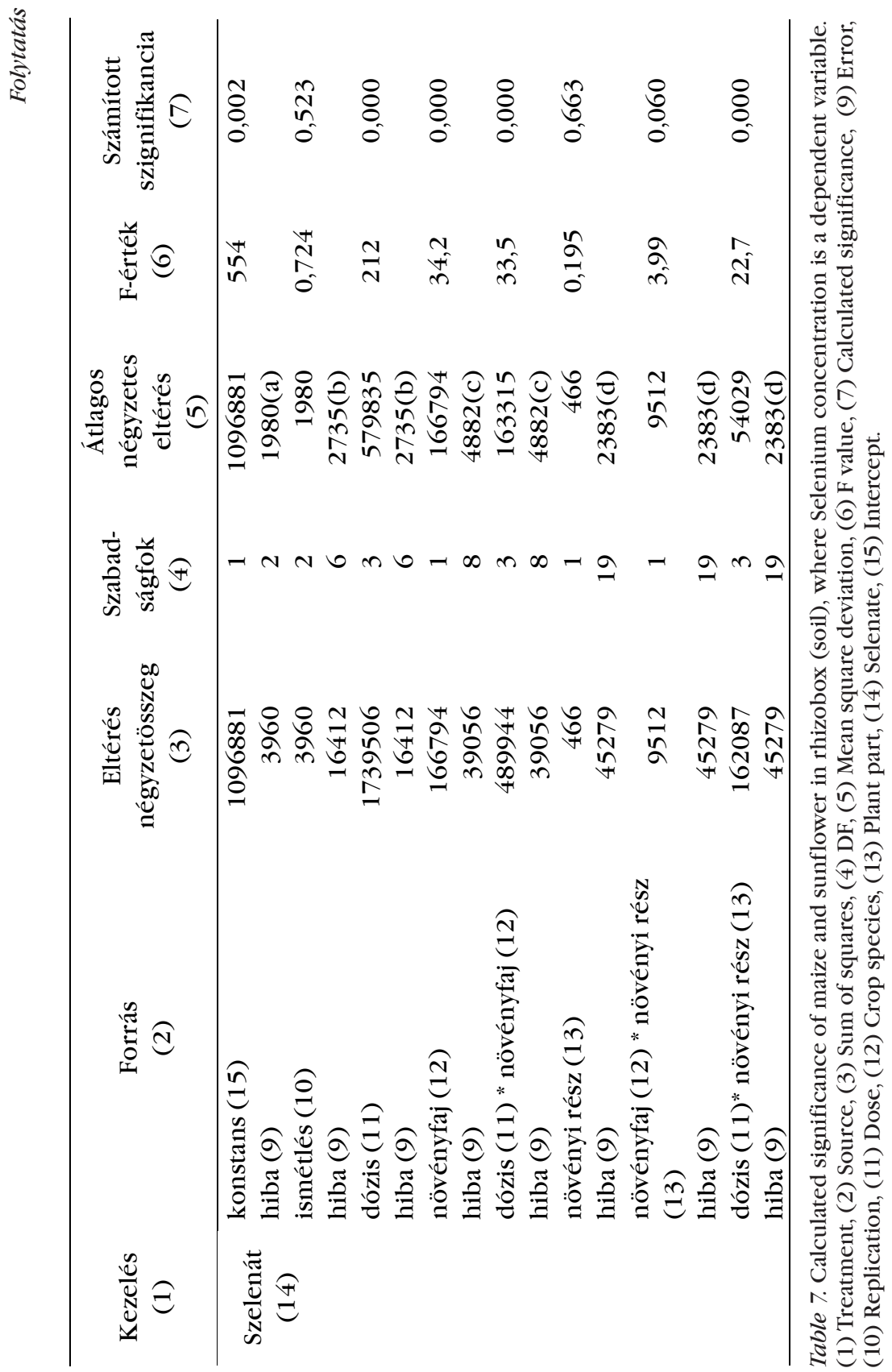


A tápoldatos kísérleteink során azt tapasztaltuk, hogy a szelén nélküli tápoldaton nevelt növények Se-tartalma viszonylag elenyészố volt, az eredetileg is meglévô szelén készletet mutatva. A szelenit és szelenát kezelések hatására a Se koncentrációja jelentősen emelkedett. Ez a növekedés a szelenát kezelés hatására intenzívebb volt, mint a szelenit kezelésnél, ugyanakkora koncentrációjú kezelések esetében. A szelenát tehát jobban hasznosuló szelénforma, mint a szelenit. Eredményeink alapján javasolhatjuk, hogy rövidtávú talajkezelés esetén, a gyorsabban és hatékonyabban, azaz a gazdaságosabban hasznosuló szelenátot célszerú használni, mivel ugyanolyan koncentrációjú szelenit és szelenátból, a növények sokkal jelentôsebb mennyiségú szelén felvételére képesek. Ugyanakkor felhívjuk a figyelmet ugyanezek okok miatt arra is, hogy ezáltal szelenát alkalmazásával könnyebb, nem megfelelố adagolás esetén, a toxikus szintet elérni.

A kísérleti növények hajtásainak és gyökereinek külön történő vizsgálata a szakirodalommal egyezô eredményt hozott. A kukorica és a napraforgó esetében is a gyökerekben mért Se-koncentrációk nagyobbak voltak a hajtásban mért értékeknél. Ez arra utal, hogy a gyökerekben, a vizsgált körülmények között a szelén akkumulációja intenzívebb volt.

A talajos kísérletben a Se-felvétel hasonlóan alakult, mint a tápoldatos kísérletben. A rizoboxos kísérletnél nem lehet szelénmentes környezetet biztosítani, mivel már a kontroll talaj is tartalmaz bizonyos mennyiségú szelént. Ennek ellenére a kontroll talajból a napraforgó növény csak viszonylag csekély mennyiségú szelént vett fel. A kukorica azonban a szelén kezelést nem kapott talajból több szelént vett fel, mint a napraforgó és ez tovább növekedett a szelenát kezelések hatására. A jelentkezett eltérésnek a két növénytípus eltérô tápanyag felvételi mechanizmusa az oka.

A tápoldatos kísérlethez hasonlóan a gyökerekben mért Se-koncentrációk nagyobbak voltak a hajtásban mért értékeknél és a szelenát szintén jobban felvehető volt, mint a szelenit.

Következtetésként kijelenthetô, hogy rendkívül fontos a talaj megfelelô szelén tartalma. A talaj Se-ellátásánál figyelembe kell vennünk azt a tényt, hogy bár jelenléte fontos a növények számára is, túl nagy koncentrációja azonban komoly veszélyt jelent a növények, állatok és így az ember számára is. A kísérletek eredményei alapján egyértelmú bizonyítékot találtunk arra vonatkozóan, hogy a tápoldatos rendszerben $1 \mathrm{mg} / \mathrm{kg}$ koncentrációjú szelenit kezelés kedvezó hatású a kukorica növény növekedésére, míg 100 mg/kg szelenit kezelés 
már erôsen toxikus hatású. A szelenát kezelés $0,1 \mathrm{mg} / \mathrm{kg}$ koncentrációban volt kedvezô, míg $10 \mathrm{mg} / \mathrm{kg}$ már növekedés gátló hatású volt a kukorica és napraforgó esetében is.

A viszonylagosan nagy szelénnel szembeni toleranciájuk alapján a kukorica és napraforgó fitoremediációra is alkalmazhatóak szelénnel szennyezett területeken, ami egy környezetbarát és viszonylag olcsó eljárás a szennyezés eltávolításához, és a talaj szerkezetét sem károsítja, viszont időigényes. Ugyanakkor az is megállapítható, hogy az átlagosnál nagyobb szelén koncentráció nem károsítja a kukoricát és a napraforgót, azaz az ilyen területeken ezek a növények biztonságosan termeszthetők.

\section{Köszönetnyilvánítás}

A szerzők köszönik a Bolyai János Kutatási Ösztöndíj, valamint a Magyar-Indiai TÉT együttmúködés (OMFB-00742/2008 (IND-17/06)) támogatását.

\section{IRODALOM}

Aubert, H.-Pinta, M.: 1977. Trace elements in soils. Elsevier scientific publishing company. New York.

Bankhofer H.: 1994. Bio-szelén. Golden Book Kiadó. Budapest.

Chengyi,Z.-Ren, J.-Xue, C.-Lin, E.: 2005. Study on the relationship between soil selenium and plant selenium uptake. Plant and Soil. 277: 197-206.

Kádár I.: 1998. Szelén forgalma a talaj-növény rendszerben. [In: Cser M. Á.-SziklaiLászló I. (szerk.) A szelén szerepe a környezetben és egészségvédelemben.] Frag Bt. Budapest.

Kádár I.: 1995. A talaj-növény-állat-ember tápláléklánc szennyezôdése kémiai elemekkel Magyarországon. Környezetvédelmi és Területfejlesztési Minisztérium MTA Talajtani és Agrokémiai Kutató Intézete. Budapest.

Kápolna E.: 2006. Szeléntartalmú élelmiszerek és étrendkiegészítők biológiai hasznosulásának vizsgálata. Doktori disszertáció. Szent István Egyetem. Alkalmazott Kémiai Tanszék. Budapest.

Kovács, B.-Gyóri, Z.-Prokisch, J.-Loch, J.-Dániel, P.: 1996. A study of plant sample preparation and inductively coupled plasma emission spectrometry parameters. Communications in Soil Science and Plant Analysis. 27. 5-8: 1177-1198.

Kovács, B.-Dániel, P.-Györi, Z.-Loch, J.-Prokisch, J.: 1998a. Studies on Parameters of Inductively Coupled Plasma Spectrometer. Communications in Soil Science and Plant Analysis. 29. 11-14: 2035-2054. 
Kovács M.-Turcsányi G.-Siller I.-Engloner A.: 1998b. A Se előfordulása Magyarország növénytársulásaiban. 85. [In: Cser M. Á.-Sziklai-László I. (szerk.) A szelén szerepe a környezetben és egészségvédelemben.] Frag Bt. Budapest.

Lteif, A.-Bashour, I.-Nimah, M.-Darwish, R.: 2005. Selenium Levels in Beqaa Valley in Lebanon. [In: Lee et al. (eds.) Plant Nutrition for Food Security. Human Health and environmental Protection.] Tsinghua University Press. Bejing. China.

Marschner, H.: 1995. Mineral Nutrition of Higher Plants. Academic Press. London.

Robb, D. A.-Pierpoint, W. S.: 1983. Metals and micronutrients: uptake and utilization by plants. Academic Press. London.

Schwarz, K.-Foltz, C. M.: 1957. Selenium as an integral part of factor 3 against dietary necrotic liver degeneration. Journal of the American Chemical Society. 79. 12: 3292-3293.

Simon L.: 1999. A talajok szennyeződése szervetlen anyagokkal. [In: Simon L. (szerk.) Talajszennyeződés, talajtisztítás.] Környezetgazdálkodási Intézet Környezet- és Természetvédelmi Szakkönyvtár és Információs Központ. Budapest.

Széles É.: 2007. Szelénvegyületek átalakulásának vizsgálata tartamkísérletből származó talaj- és növénymintákban. Doktori disszertáció. Debreceni Egyetem. Mezôgazdaságtudományi Kar. Élelmiszertudományi, Minôségbiztosítási és Mikrobiológiai Intézet. Debrecen.

Takács S.: 2001. A nyomelemek nyomában. Medicina Könyvkiadó Rt. Budapest.

Terry, N.-Zayed, A. M.-Desouza, M. P., Tarun, A. S.: 2000. Selenium in higher plants. Annual Review of Plant Physiology and Plant Molecular Biology. 51: 401-432.

A szerzók levelezési címe - Address of the authors:

Nagy Kinga-Dr. Kovács Béla

Debreceni Egyetem Agrár- és Múszaki Tudományok Centruma

Élelmiszertudományi, Minôségbiztosítási és Mikrobiológiai Intézet

Debrecen

Böszörményi út 138.

H-4032

Dr. Lévai László

Debreceni Egyetem Agrár- és Múszaki Tudományok Centruma

Növénytudományi Intézet, Mezőgazdasági Növénytani és Növényélettani Tanszékcsoport Debrecen

Böszörményi út 138.

H-4032 